\title{
The Policy Challenge of the Irregular Migration in Europe
}

\section{Iraj Roudgar*}

Universiti Teknologi Malaysia (UTM), Kuala Lumpur, Malaysia

\begin{abstract}
The flows of unauthorized immigrants across European countries have brought a social-political threat and EU policymakers are under the increasing public and political pressures. There might have been neglected some important facts underlying irregular migration in Europe. This paper reviews the root of the forcibly displaced persons worldwide to Europe and policy challenge which provides a perspective from a political approach.
\end{abstract}

Keywords: Irregular migration; Politics; External borders, EU policies

\section{Introduction}

Globalization has changed the traditional political world map and caused of flattened thus the political and geographical boundaries disappeared. It has also resulted in an accelerated movement of people as a global phenomenon. According to the United Nations, the number of international migrants worldwide has continued to grow rapidly over the past fifteen years, reaching 244 million in 2015, and about 76 million are living in Europe [1]. In a part of the social phenomenon, the forces of irregular migration in European countries have brought a social-political threat for any states in the region. Consequently, EU policy makers are under the increasing public and political pressures to the flows of unauthorized immigrants in any receiving country. So, what is most significant deal to curb the further flows?

The rise of the Islamic State in 2014 tailed the Arab Springs in the Middle East and North Africa was that a consequence of the failed democracy movement in the region. The Islamic extremist group has brought civil wars and political instability in Syria, Iraq, and Libya and also a new pattern of terrorist attack in the worldwide. It has also resulted in a huge wave of people movement as a new face of forcibly displaced persons worldwide, particularly to European states. This humanitarian crisis in the MENA has demonstrated the EU inefficiency policies in borders controlling. For example, Frontex in 2016 informed that more than 1.8 million people crossed the European Union's borders illegally in 2015 [2]. Meanwhile, European Political Strategy Centre reported, about 630,000 irregular migrants reached Italy via the Central Mediterranean from 2011 to 2016 [3].

\section{Discussion}

According to Eurostat, 1,400,000 people left their origin of birth and seeking for European countries in 2016. The Figure 1 below shows by origin asylum applications from all countries to European Union Member States and European Free Trade Association (EFTA) countries [4].

The Figure shows here reflect the number of asylum applications filed in all Member States and should not be taken as equivalent to the number of individual asylum seekers present in the countries. Accordingly, there has been an acceleration of forcibly displaced persons from the Middle East and North Africa to European countries and is increasingly growing annually. The mass flows not only led by better opportunities for a better life in destinations, but also pushed by political conditions at home. Poor political climate in the region such; political instability, civil wars, and particular religious persecution can have an effect on the people movement and be considered as a high push factors. On the other hands, political motivational framing by policy decisions of potential host countries, concerning issues of freedom, welfare and employment encouraged the immigrants.

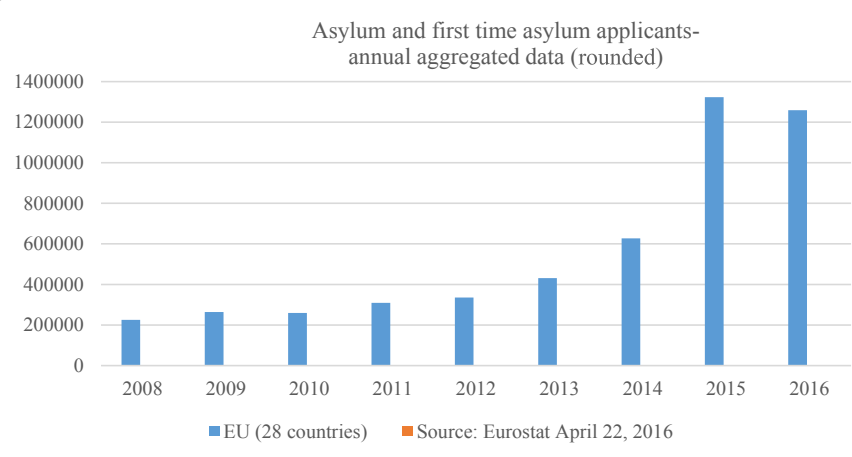

Figure 1: Origin asylum applications.

Today we have witnessed their regular migration flows and in particular relocation by sea, primarily along the Central and Eastern Mediterranean routes, has increased exponentially over the past years. So, the threat of the mass flows occurring at the external borders, given the measures in place at the borders and within the EU, which will impact EU homeland security. It has brought an uncertain society as an internal threat to homeland security interests linked to the mobility and security.

Migration policies play an important role in determining regular/ legal migration, conditions and consequences of international migration. There seem to be non-realistic policy that is associated with the irregular migration in European countries and need to major reform to migration policies. One innovative solution may be to change the migration policies style, such as improving efficiency, getting rid of mismanagement and made to clear policies and legislative systems to curb the further mass flows in EU. As EU immigration policy; European countries have agreed to develop a common immigration policy to ensure that legal migration to the EU is well manage [5]. But there is not any common policy for such irregular migration to manage and cooperation with transit countries. A closer cooperation between the EU and the transit countries will be an important step towards realizing these prospects.

*Corresponding author: Iraj Roudgar, Universiti Teknologi Malaysia (UTM), Kuala Lumpur, Malaysia, Tel: 0060176075283, E-mail: roudgariraj@gmail.com

Received May 02, 2017; Accepted June 20, 2017; Published June 23, 2017

Citation: Roudgar I (2017) The Policy Challenge of the Irregular Migration in Europe. Review Pub Administration Manag 5: 213. doi:10.4172/2315-7844.1000213

Copyright: (C) 2017 Roudgar I. This is an open-access article distributed under the terms of the Creative Commons Attribution License, which permits unrestricted use, distribution, and reproduction in any medium, provided the original author and source are credited. 
Citation: Roudgar I (2017) The Policy Challenge of the Irregular Migration in Europe. Review Pub Administration Manag 5: 213. doi:10.4172/23157844.1000213

Page 2 of 2

Hence, the irregular migration from MENA remained as a most challenging issue for policy makers in political, cultural and economic impact of the phenomenon in European societies. The age of the unthinkable and new world disorder, we have witnessed new challenges such; a political event in the East implications of the Western societies, and contrariwise. In this complexity and indeterminate field, policy makers faced with new challenges that differ with previous experiences and it is necessary to change the general policies based on new global environment.

\section{Conclusion}

This perspective does not address human trafficking as illegal or irregular migration.

\section{References}

1. International Migration Report (2015) Department of Economic and Social Affairs.

2. Frontex (2016) Greece and Italy continued to face unprecedented number of migrants in December.

3. European Political Strategy Centre (EPSC) (2017) Irregular migration via the Central Mediterranean.

4. Eurostat (2016) European Commission.

5. European Commission (2016) EU Immigration Portal, EU migration policy. 